\title{
Efektivitas Model Pembelajaran Talking Stick Terhadap Kemampuan Komunikasi Matematis Siswa pada Pokok Bahasan Kubus dan Balok
}

\author{
Devi Yulianti ${ }^{1}$, Resy Nirawati ${ }^{2}$, Rika Wahyuni ${ }^{3}$ \\ STKIP Singkawang, Singkawang, Indonesia \\ deviy9349@gmail.com ${ }^{1}$, resynirawaty@upi.edu ${ }^{2}$, rikawahyuni142@gmail.com ${ }^{3}$
}

\author{
Keywords : \\ Efektifitas, Pembelajaran \\ Talking Stick, Kemampuan \\ Komunikasi Matematis, Kubus \\ dan Balok
}

\begin{abstract}
Penelitian ini bertujuan untuk: 1) mengetahui efektivitas model pembelajaran Talking Stick terhadap kemampuan komunikasi matematis siswa 2) untuk mengetahui ketuntasan belajar siswa 3) untuk mengidentifikasi aktivitas siswa melalui model pembelajaran Talking Stick 4) untuk mengidentifikasi motivasi belajar siswa terhadap model pembelajaran Talking Stick. Penelitian ini dilaksanakan di kelas VIII SMP Torsina 1 Singkawang dengan dengan menggunakan metode eksperimen semu dengan desain Pretest Posttest Control Group Design. Sampel penelitian diambil dengan teknik Sampling Jenuh. Teknik analisis data yang digunakan untuk mengetahui perbedaan peningkatan pemahaman konsep matematis siswa di kelas kontrol dan kelas eksperimen yaitu dengan menggunakan uji-t, untuk mengetahui aktivitas siswa yaitu dengan menggunakan persentase aktivitas siswa per indikator dan untuk mengetahui motivasi belajar siswa menggunakan rata-rata dari skor angket yang diberikan. Berdasarkan analisis data yang diperoleh bahwa $t_{\text {hitung }}=6,112>t_{\text {tabel }}=2,00, \quad$ sehingga terdapat perbedaan peningkatan kemampuan komunikasi matematis siswa di kelas kontrol dan di kelas eksperimen pada materi kubus dan balok. Untuk ketuntasan hasil belajar yaitu 70,8 > 59,6. Untuk KKM 68, hal ini menunjukkan bahwa kelas kelas eksperimen lebih tinggi dari pada KKM kelas kontrol yaitu 70,8 > 68. Sehingga kelas eksperimen ketuntasan belajar siswa dikategorikan tuntas. Rata-rata aktivitas siswa sebesar 80,26\%, dengan kategori aktif. Untuk motivasi diperoleh rata-rata jumlah skor total seluruh indikator motivasi belajar sebesar 81,25 dengan kategori tinggi. Sehingga, model pembelajaran talking stick untuk meningkatkan kemampuan komunikasi matematis siswa efektif dalam pembelajaran pada pokok bahasan kubus dan balok.
\end{abstract}




\section{PENDAHULUAN}

Matematika merupakan ilmu dasar yang mempunyai peran penting dalam perkembangan ilmu pengetahuan dan teknologi. Matematika merupakan salah satu pelajaran yang sangat penting dalam pengembangan potensi diri di sekolah. Hal ini sejalan dengan pendapat (Rika dkk, 2018) yang menyatakan bahwa matematika merupakan salah satu mata pelajaran dalam pendidikan formal yang wajib dipelajari di setiap jenjang pendidikan di Indonesia. Selain itu, pembelajaran matematika di kelas tidak hanya menitikberatkan pada penguasaan materi untuk menyelesaikan masalah secara matematis (Buyung \& Resy, 2018:21). Kurikulum matematika dijalankan sesuai dengan kebutuhan dan terus mengalami perubahan sesuai perkembangan masyarakat Indonesia. Salah satu bentuk komunikasi matematis adalah kegiatan memahami matematika dan mengerti unsure-unsur matematika. Memahami matematika memiliki peran sentral dalam pembelajaran matematika, sebab kegiatan memahami mendorong siswa belajar bermakna secara aktif.

Kesulitan siswa mempelajari mata pelajaran matematika disebabkan oleh banyak faktor. Salah satu faktor penyebab siswa tidak mengetahui kaitan antar konsep yang dipelajari serta cara mengkomunikasikannya. Komunikasi dalam penelitian ini dibatasi yakni dengan komunikasi tertulis. Pengetahuan matematika akan diperoleh siswa melalui proses belajar mengajar. Belajar akan lebih berhasil apabila sudah diketahui tujuan yang akan dicapai. Tujuan pembelajaran matematika yang dirumuskan oleh National Countil of Teacher of Mathematics (NCTM) (2000;13) adalah belajar untuk (mathematical communication), belajar untuk bernalar (mathematical reasoning), belajar untuk memecahkan masalah (mathematical problem solving), belajar untuk mengaitkan ide (mathematical connection), dan pembentukan sikap positif terhadap matematika (positive attitude toward mathematics). Berdasarkan tujuan-tujuan tersebut, terlihat bahwa kemampuan komunikasi matematis siswa merupakan tujuan penting dalam pembelajaran matematika.

Rendahnya kemampuan komunikasi matematis siswa dialami oleh SMP Torsina 1 Singkawang, hal ini terlihat dari hasil pra riset yang dilakukan oleh penulis dengan soal yang berkaitan sesuai indikator kemampuan komunikasi matematis siswa yaitu, 1) Menggambar, yaitu membuat gambar, diagram, atau tabel secara lengkap dan benar, 2) Ekspresi matematika, kemampuan dalam menggunakan istilahistilah, notasi-notasi matematika dan struktur-strukturnya untuk menyajikan ide, menggambarkan hubungan-hubungan dan model-model situasi, 3) Menulis, yaitu menjelaskan secara matematis, masuk akal dan jelas serta tersusun secara sistematis.

Soal diberikan kepada 25 orang siswa dan hasilnya kemampuan komunikasi matematis siswa masih sangat rendah untuk ketiga indikator komunikasi tersebut yaitu untuk indikator menggambar terdapat 4 orang siswa (16\%) yang hanya dapat menjawab dan 21 orang siswa (84\%) yang tidak dapat menyatakan dalam bahasa atau simbol matematik, indikator ekspresi matematika terdapat 3 orang siswa (12\%) yang dapat menjawab dan 13 orang siswa (52\%) yang tidak dapat membuat gambar, indikator menulis terdapat 10 orang siswa (40\%) yang dapat menjawab dan 15 orang siswa $(60 \%)$ yang tidak dapat menjelaskan secara matematis, masuk akal dan jelas serta tersusun secara sistematis.

Selain itu, berdasarkan hasil ulangan tengah semester (MID) diperoleh rata-rata hasil belajar siswa dengan persentase 56\% dan ujian akhir sekolah (UAS) diperoleh rata-rata hasil belajar siswa dengan persentase $52 \%$ tahun pelajaran sebelumnya. Dari hasil persentase tersebut bahwa siswa yang tidak mengalami ketuntasan dalam materi sistem persamaan linear dua variabel $53 \mathrm{~S} \%$. Nilai hasil tes siswa masih jauh lebih rendah dari pencapaian nilai KKM yaitu 68 .

Pembelajaran yang masih bersifat langsung mengakibatkan aktivitas siswa di kelas menjadi cenderung pasif. Siswa hanya menerima apa yang disampaikan oleh guru tanpa melakukan usaha untuk mencoba mencari dan mengolah kembali informasi terkait materi yang dipelajari, serta masih terdapat beberapa siswa yang terlihat mengantuk dan malas untuk mendengarakan dan mencatat hal-hal yang 
disampaikan guru selama proses pembelajaran berlangsung. Padahal disetiap proses pembelajaran, aktivitas siswa merupakan bagian yang sangat penting dan sangat diperlukan.

Menurut Sardiman (2014;96) menyatakan bahwa aktivitas merupakan prinsip atau asas yang sangat penting di dalam interaksi belajar-mengajar. Aktivitas belajar merupakan aktivitas yang bersifat fisik/jasmani maupun rohani. Kaitan antar keduanya akan membuahkan aktivitas belajar yang optimal. Berdasarkan hasil observasi aktivitas siswa yang dilakukan oleh penulis serta wawancara dengan salah satu guru mata pelajaran matematika di sekolah tersebut dan memberikan angket motivasi belajar yang dilakukan oleh penulis di SMP Torsina 1 Singkawang. Dari hasil observasi yang dilakukan penulis diperoleh data aktivitas siswa pada pembelajaran matematika dikelas adalah sebagai berikut.

Tabel 1 Aktivitas siswa pada pembelajaran matematika di kelas VIII

\begin{tabular}{|c|c|c|}
\hline Aspek Penilaian Aktivitas & Jumlah siswa & Persentase \\
\hline $\begin{array}{l}\text { Listening activities, medengarkan apa yang } \\
\text { disampaikan guru. }\end{array}$ & 16 & $64 \%$ \\
\hline $\begin{array}{l}\text { Oral activites, bertanya pada guru apabila tidak } \\
\text { mengerti atau binggung. }\end{array}$ & 7 & $28 \%$ \\
\hline $\begin{array}{l}\text { Drawing activities, dapat menggambar, } \\
\text { menuliskan simbol, dan mengekspresikan. }\end{array}$ & 8 & $32 \%$ \\
\hline $\begin{array}{l}\text { Motor activities, dapat membangun komunikasi } \\
\text { dengan guru. }\end{array}$ & 4 & $16 \%$ \\
\hline $\begin{array}{l}\text { Mental aktivities, menanggapi apa yang } \\
\text { disampaikan guru. }\end{array}$ & 5 & $20 \%$ \\
\hline $\begin{array}{l}\text { Emotional activities, bersemangat, tenang, dalam } \\
\text { mengikuti pelajaran matematika. }\end{array}$ & 9 & $36 \%$ \\
\hline
\end{tabular}

Berdasarkan Tabel 1 diperoleh:

1. Terdapat 16 orang siswa dari 25 siswa dengan persentase $64 \%$ mendengarkan apa yang disampaikan oleh guru, sedangkan 9 orang siswa lainnya dengan persentase $36 \%$ tidak mendengarkan apa yang disampaikan oleh guru atau masih sibuk sendiri.

2. Terdapat 7 orang siswa dari 25 siswa dengan persentase $28 \%$ yang bertanya pada guru apabila tidak mengerti atau binggung, sedangakan 18 orang siswa lainnya dengan persentase $72 \%$ masih kurang aktif bertanya pada guru apabila tidak mengerti atau binggug.

3. Terdapat 8 orang siswa dari 25 siswa dengan persentase $32 \%$ dapat menggambar, menuliskan simbol, dan mengekspresikan, sedangkan 17 orang siswa lainnya dengan persentase $68 \%$ tidak dapat menggambar, menuliskan simbol, dan mengekspresikan.

4. Terdapat 4 orang siswa dari 25 siswa dengan persentase $16 \%$ dapat membangun komunikasi dengan guru, sedangkan 21 orang siswa lainnya tidak dapat membangun komunikasi dengan guru.

5. Terdapat 5 orang siswa dari 25 siswa dengan persentase $20 \%$ menanggapi apa yang disampaikan guru, sedangkan 20 orang siswa lainnya dengan persentase $80 \%$ hanya menunggu jawaban dari teman - temannya.

6. Terdapat 9 orang siswa dari 25 siswa dengan persentase $36 \%$ yang bersemangat, tenang, dalam mengikuti pembelajaran matematika sampai akhir, sedangkan 16 orang siswa lainnya dengan persentase $64 \%$ mulai bosan dan menagntuk dalam mengikuti pembelajaran matematika samapi akhir. 
Selain observasi kelas mengenai aktivitas siswa penulis juga memberikan angket motivasi belajar siswa terhadap pembelajaran matematika angket motivasi belajar siswa berupa hal - hal yang positif dan juga negatif. Hal ini sejalan dengan pendapat (Sumiati dan Asra, 2011:59) yang menyatakan

motivasi adalah sesuatu yang mendorong siswa untuk berperilaku yang langsung menyebabkan munculnya perilaku dalam belajar. Motivasi adalah kekuatan yang mencapai pendorong kegiatan individu untuk melakukan suatu kegiatan mencapai tujuan (Abdul Majid, 2009:152). Sedangkan menurut Sardiman (2014:85) motivasi berfungsi untuk mendorong manusia untuk berbuat, menentukan arah perbuatan, untuk mencapai tujuan dan menyeleksi perbuatan yakni perbutan mana yang akan dikerjakan. Dari hasil pemberian angket motivasi yang dilakukan penulis diperoleh data motivasi belajar siswa terhadap pembelajaran yang dilakuakan oleh guru dikelas VIII B, dapat dilihat pada Tabel 2

Tabel. 2 Motivasi belajar siswa terhadap model pembelajaran langsung yang dilakukan oleh guru di kelas VIII B

\begin{tabular}{lcc}
\hline \multicolumn{1}{c}{ Kriteria Motivasi } & $\begin{array}{c}\text { Jumlah } \\
\text { siswa }\end{array}$ & Persentase \\
\hline Senang belajar matematika. & 7 & $28 \%$ \\
\hline Semangat belajar matematika. & 6 & $24 \%$ \\
\hline Memahami materi matematika dengan jelas . & 4 & $16 \%$ \\
\hline Aktif berdiskusi dengan teman saat belajar matematika. & 8 & $32 \%$ \\
\hline $\begin{array}{l}\text { Berusaha dengan keras untuk mencari solusi dari } \\
\text { permasalahan matematika. }\end{array}$ & 7 & $28 \%$ \\
\hline Peduli dengan penjelasan matematika yang guru sampaikan. & 4 & $16 \%$ \\
\hline Berkonsentrasi saat belajar matematika. & 8 & $32 \%$ \\
\hline \begin{tabular}{l} 
Penjelasaan yang disampaikan guru membuat binggung. \\
\hline
\end{tabular} & 17 & $68 \%$ \\
\hline
\end{tabular}

Dari Tabel 2 motivasi diperoleh 68\% siswa menyatakan bahwa pembelajaran matematika bukan merupakan pembelajaran yang menyenangkan sedangkan $28 \%$ siswa menyukai pembelajaran matematika dengan pembelajaran langsung. Berdasarkan hasil observasi kelas atau pengamatan yang dilakukan penulis di SMP Torsina 1 Singkawang, model pembelajaran yang dilakukan oleh guru untuk mengajar masih menggunakan model pembelajaran langsung. Menurut Jihad dan Haris (2008:27) model pembelajaran langsung merupakan model pembelajaran yang dirancang secara khusus untuk menunjang proses belajar siswa berkenaan dengan pengetahuan prosedural dan pengetahuan deklaratif yang terstruktur dengan baik dan dapat dipelajari selangkah demi selangkah. Langkah-langkah pembelajaran langsung menurut Jihad dan Haris (2008:29) yaitu: 1) guru menyampaikan tujuan pembelajaran dan mempersiapkan siswa, 2) guru mendemonstrasikan pengetahuan dan keterampilan, 3) guru membimbing penelitian, 4) guru mengecek pemahaman dan memberikan umpan balik, 5) guru memberikan latihan dan penerapan konsep. Pada proses pembelajaran langsung hanya berpusat pada guru sehingga tingkat kemampuan komunikasi matematis siswa rendah, selaian itu aktivitas siswa dan motivasi belajar siswa juga masih rendah. Hal ini berarti model pembelajaran langsung mempengaruhi aktivitas siswa dan motivasi belajar siswa dikelas pada saat pembelajaran matematika yaitu siswa cepat merasa bosan, tidak semangat, dan asyik dengan diri sendiri atau sibuk sendiri.

Berdasarkan hal-hal tersebut, diharapkan guru dapat menggunakan model-model pembelajaran yang dapat membantu siswa dalam meningkatkan kemampuan komunikasi matematis siswa dalam pembelajaran matematika. Pembelajaran itu sendiri merupakan suatu proses interaksi antara guru dengan siswa, baik interaksi secara langsung seperti kegiatan tatap muka maupun secara tidak langsung, yaitu dengan menggunakan berbagai media (Rusman, 2012:144).Dalam upaya meningkatkan kemampuan komunikasi matematis siswa perlu adanya diterapkan proses pembelajaran 
yang mampu memberikan lebih banyak kesempatan kepada siswa untuk berpartisipasi aktif dalam mengikuti proses pembelajaran yang berlangsung. Model pembelajaran kooperatif yang dapat memberikan waktu kepada siswa untuk berpartisipasi aktif adalah Talking Stick.

Model pembelajaran Talking Stick merupakan suatu cara yang efektif untuk melaksanakan pembelajaran yang mampu mengaktifkan siswa. Model pembelajaran Talking Stick adalah suatu

model pembelajaran kelompok dengan bantuan tongkat, kelompok yang memegang tongkat terlebih dahulu wajib menjawab pertanyaan dari guru setelah siswa mempelajari materi pokoknya, selanjutnya kegiatan tersebut diulang terus-menerus sampai semua kelompok mendapat giliran untuk menjawab pertanyaan dari guru. Dan dapat dilakukan secara mandiri oleh siswa. Berdasarkan hasil penelitian yang dilakukan oleh Bambang (2012) diketahui beberapa hal berkenaan dengan komunikasi siswa kelas VIII SMP Negeri 2 Pejagoan kelas unggulan di SMP Negeri 2 Pejagoan kemampuan komunikasi matematis siswa meningkat dengan menggunakan metode Talking stick, hal ini ditunjukan oleh peningkatan persentase rerata kemampuan komunikasi matematis. Hasil penelitian menunjukkan rerata kemampuan komunikasi matematis $62,77 \%$ pada siklus I meningkat menjadi $75,74 \%$ pada siklus II. Ketuntasan hasil belajar matematika meningkat, dari siklus I siswa yang telah mencapai Kriteria Ketuntasan Minimal (KKM) sebanyak 25\% dengan rerata nilai 57,41, meningkat menjadi $91 \%$ pada siklus II dengan rerata nilai 75,69 .

Selain itu, menurut hasil penelitian Kimberly Fujioka (2012) bahwa model pembelajaran talking stick dapat digunakn oleh guru untuk mengajar matematika disekolah dasar, sekolah menengah pertama dan sekolah menengah atas. Model pembelajaran kooperatif tipe talikg stick lebih cenderung berpusat kepada keaktifan siswa dalam proses pembelajaran. Agar siswa dapat aktif dalam proses pembelajaran tentunya siswa harus memiliki motivasi yang tinggi untuk mengikuti proses pembelajaran tersebut.

Dari uraian di atas penulis ingin menerapkan Model Pembelajaran Talking Stick untuk meningkatkan kemampuan komunikasi matematis siswa pada materi kubus dan balok di Kelas VIII Sekolah Menengah Pertama Torsina 1 Singkawang.

\section{METODE}

Metode yang digunakan dalam penelitian ini adalah metode penelitian (True Eksperimen), yaitu eksperimen murni tetap seperti murni metode eksperimen yang tidak memungkinkan peneliti melakukan pengontrolan penuh terhadap variabel dan kondisi eksperimen (Nana Syaodih 2010:207). Pada penelitian ini, peneliti mengujicobakan model pembelajaran kooperatif tipe Talking Stick terhadap peningkatan kemampuan komunikasi matematis siswa, kemudian membandingkan hasil tes kemampuan komunikasi matematis siswa yang diajarkan dengan model pembelajaran Talking Stick (kelas eksperimen) dengan siswa yang diajarkan dengan pembelajaran langsung (kelas kontrol).

Adapun populasi dalam penelitian ini adalah seluruh siswa kelas VIII yang terdiri dari 2 kelas yaitu kelas VIII A, dan VIII B, dengan jumlah total siswa sebanyak 46 orang. Pengambilan sampel menggunakan teknik probability sampling yaitu simple random sampling. Probability sampling adalah teknik pengambilan sampel yang memberi peluang yang sama bagi setiap unsur (anggota) populasi untuk dipilih menjadi anggota sampel. Sampel yang diambil dalam penelitian ini terdiri dari 2 kelas, satu kelas sebagai kelas eksperimen yaitu kelas VIIA dan satu kelas sebagai kelas kontrol yaitu kelas VIIB. Pengambilan sampel yang digunakan adalah Simple Random Sampling, karena pengambilan anggota sampel dari populasi dilakukan secara acak tanpa memperhatikan strata yang ada dalam populasi itu.

Teknik pengumpulan data yang dimaksud dalam penelitian ini adalah lembar tes kemampuan komunikasi matematis. Lembar tes yang digunakan yaitu berupa lembar tes awal (Pre-test) dan akhir 
(Post-test) yang terdiri dari tiga butir soal. Selain lembar tes, instrumen yang digunakan dalam penelitian ini adalah lembar pengamatan aktivitas digunakan untuk melihat keterlibatan siswa dalam proses pembelajaran. Angket digunakan untuk mengetahui motivasi belajar siswa dengan menggunakan lembar angket motivasi belajar siswa yang terdiri dari 10 pernyataan berbentuk pilihan skala likert dengan memberi tanda centang $\left({ }^{\vee}\right)$.

Instrumen pengumpulan data yang dimaksud dalam penelitian ini berupa soal tes kemampuan komunikasi matematis, lembar pengamatan, dan lembar angket. Instrumen pengumpulan data berupa tes terlebih dulu di uji validitas, reliabilitas, daya pembeda dan tingkat kesukarannya.Validitas bertujuan agar tes yang digunakan benar-benar untuk mengukur kemampuan siswa dalam menyelesaikan soal kubus dan balok, maka instrumen yang telah disusun diukur dengan validitas tes. Adapun hasil perhitungan validitas dapat dilihat pada Tabel 3.

Tabel 3. Perhitungan Validitas Uji Coba Soal

\begin{tabular}{ccccc}
\hline Soal & Nomor & Nomor & Nomor & Nomor \\
& $\mathbf{1}$ & $\mathbf{2}$ & $\mathbf{3 a}$ & $\mathbf{3 b}$ \\
\hline Validitas & 0,70 & 0,67 & 0,79 & 0,53 \\
Kriteria & Tinggi & Tinggi & Tinggi & Cukup \\
\hline
\end{tabular}

Reliabilitas menunjukkan pada suatu pengertian bahwa suatu instrumen cukup dapat dipercaya untuk digunakan sebagai alat pengumpulan data karena instrumen tersebut sudah baik. Berdasarkan hasil perhitungan uji coba soal diperoleh bahwa reliabilitas sebesar 0,61 dengan kriteria tinggi. Daya pembeda adalah kemampuan dari tes tersebut dalam memisahkan antara subjek yang pandai dengan subjek yang kurang pandai. Adapun hasil perhitungan daya pembeda dapat dilihat pada Tabel 4.

Tabel 4. Perhitungan Daya Pembeda Uji Coba Soal

\begin{tabular}{llcll}
\hline \multicolumn{1}{c}{ Soal } & $\begin{array}{c}\text { Nomor } \\
\mathbf{1}\end{array}$ & $\begin{array}{c}\text { Nomor } \\
\mathbf{2}\end{array}$ & $\begin{array}{c}\text { Nomor } \\
\mathbf{3 a}\end{array}$ & $\begin{array}{c}\text { Nomor } \\
\mathbf{3 b}\end{array}$ \\
\hline DP & 0,57 & 0,38 & 0,36 & 0,21 \\
Kriteria & Baik & Cukup & Cukup & Cukup \\
\hline
\end{tabular}

Tingkat kesukaran bertujuan untuk mengkaji soal-soal soal tes yang diujicobakan dari sisi kesulitannya, sehingga dapat diperoleh soal-soal yang termasuk dalam kategori mudah, sedang dan sukar.Adapun hasil perhitungan tingkat kesukaran dapat dilihat pada Tabel 5.

Tabel 5. Perhitungan Tingkat Kesukaran Uji Coba Soal

\begin{tabular}{ccccc}
\hline Soal & $\begin{array}{c}\text { Nomor } \\
\mathbf{1}\end{array}$ & $\begin{array}{c}\text { Nomor } \\
\mathbf{2}\end{array}$ & $\begin{array}{c}\text { Nomor } \\
\mathbf{3 a}\end{array}$ & $\begin{array}{c}\text { Nomor } \\
\mathbf{3 b}\end{array}$ \\
\hline TK & 0,71 & 0,62 & 0,79 & 0,61 \\
Kriteria & Mudah & Sedang & Mudah & Sedang \\
\hline
\end{tabular}

\section{HASIL DAN PEMBAHASAN}

Berdasarkan analisis data rata-rata posttest kemampuan komunikasi matematis siswa (posttest) kelas eksperimen lebih tinggi yaitu sebesar 73,39 dibandingkan rata-rata kemampuan komunikasi matematis siswa kelas kontrol yaitu sebesar 59,35. Selain itu, berdasarkan uji hipotesis menunjukkan bahwa Ho ditolak dan Ha diterima sehingga terdapat perbedaan yang signifikan antara kelas eksperimen yang menggunakan model pembelajaran Talking Stick dan kelas kontrol yang menggunakan model pembelajaran langsung yaitu kemampuan komunikasi matematis siswa kelas ekperimen lebih tinggi dibanding kemampuan komunikasi matematis siswa kelas kontrol. 
Hal ini dikarenakan pembelajaran matematika dengan menggunakan model pembelajaran Talking Stick lebih efektif daripada pembelajaran matematika dengan menggunakan model pembelajaran langsung. Perbedaan kemampuan komunikasi matematis siswa disebabkan karena adanya perbedaan yang ditimbulkan oleh masing-masing perlakuan terhadap kemampuan komunikasi matematis siswa. Siswa yang diberi perlakuan dengan menggunakan model pembelajaran Talking Stick mendapat kontribusi lebih baik daripada siswa yang diberi perlakuan dengan pembelajaran langsung.

Model pembelajaran Talking Stick merupakan suatu cara yang efektif untuk melaksanakan pembelajaran yang mampu mengaktifkan siswa. Model pembelajaran Talking Stick adalah suatu model pembelajaran kelompok dengan bantuan tongkat, kelompok yang memegang tongkat terlebih dahulu wajib menjawab pertanyaan dari guru setelah siswa mempelajari materi pokoknya, selanjutnya kegiatan tersebut diulang terus-menerus sampai semua kelompok mendapat giliran untuk menjawab pertanyaan dari guru. Dan dapat dilakukan secara mandiri oleh siswa.Hasil ini sejalan dengan penelitian yang dilakukan oleh Bambang Priyo (2015) yang menyimpulkan bahwa kemampuan komunikasi matematis siswa yang memperoleh model pembelajaran matematika Talking Stick lebih baik dari pada siswa yang memperoleh pembelajaran secara langsung.

Ketuntasan hasil belajar siswa dapat dilihat dari hasil Posttest menunjukkan bahwa nilai rata-rata kelas eksperimen lebih tinggi dari pada kelas kontrol dan nilai KKM. Sedangkan nilai rata-rata kelas kontrol lebih kecil dari pada nilai KKM. Hal ini menunjukkan bahwa kelas kelas eksperimen lebih tinggi dari pada KKM yaitu 70,8 > 68. Dengan demikian dapat disimpulkan bahwa ketuntasan kemampuan komunikasi matematis siswa pada pokok bahasan kubus dan balok yang diajarkan dengan menggunakan model Talking Stick lebih tuntas dari pada yang diajarkan menggunakan model pembelajaran yang bersifat langsung. Untuk mengetahui ketuntasan belajar siswa dapat dilihat dari analisis hasil posttest kemampuan komunikasi matematis siswa pada kelas kontrol dan eksperimen rata-rata skor untuk setiap indikator kemampuan komunikasi matematis siswa dapat dilihat pada tabel 26 sebagai berikut.

Tabel 6. Rata-rata Skor Indikator Hasil Postest Kemampuan Komunikasi Matematis Siswa Kelas Eksperimen dan Kelas Kontrol

\begin{tabular}{|c|c|c|c|c|c|c|}
\hline \multirow[b]{2}{*}{ Kelas } & \multirow[b]{2}{*}{ KKM } & \multicolumn{3}{|c|}{ Rata-rata Skor Tiap Indikator } & \multirow{2}{*}{$\begin{array}{c}\text { Nilai Rata- } \\
\text { rata }\end{array}$} & \multirow[b]{2}{*}{ Nilai } \\
\hline & & Indikator & $\begin{array}{c}\text { Rata-rata skor } \\
\text { maksimal }\end{array}$ & $\begin{array}{l}\text { rata- } \\
\text { rata }\end{array}$ & & \\
\hline \multirow{3}{*}{ Eksperimen } & \multirow{6}{*}{68} & Ekspresi & 3 & 2.48 & \multirow{3}{*}{0.708} & \multirow{3}{*}{70.8} \\
\hline & & Menggambar & 3 & 2.43 & & \\
\hline & & Menulis & 4 & 2.50 & & \\
\hline \multirow{3}{*}{ Kontrol } & & Ekspresi & 3 & 1.65 & \multirow{3}{*}{0.596} & \multirow{3}{*}{59.6} \\
\hline & & Menggambar & 3 & 1.70 & & \\
\hline & & Menulis & 4 & 2.50 & & \\
\hline
\end{tabular}

Dari hasil posttest pada Tabel 26 diperoleh bahwa nilai rata-rata pada setiap indikator untuk indikator Ekspresi di kelas eksperimen adalah 2,48 sedangkan nilai rata-rata kelas kontrol adalah 1,65. Pada indikator menggambar nilai rata-rata di kelas eksperimen adalah 2,43 sedangkan nilai rata-rata kelas kontrol adalah 1,70, dan untuk indikator menulis nilai rata-rata di kelas eksperimen adalah 2,50 sedangkan nilai rata-rata kelas kontrol adalah 2,50. Selain itu, untuk nilai rata-rata seluruh indikator di kelas eksperimen adalah 0.708 sedangkan di kelas control adalah 0,596. Hal ini menunjukkan bahwa kelas eksperimen mempunyai rata-rata yang lebih tinggi dibanding kelas kontrol dengan selisih 0,112. KKM untuk pelajaran matematika di Sekolah Torsina 1 Singkawang adalah 68.

Lembar observasi digunakan untuk mengetahui aktivitas siswa selama mengikuti pembelajaran dengan menggunakan model Talking Stick.. Pengamatan yang dilakukan selama dua kali pertemuan yang dilakukan oleh 3 orang observer, secara ringkas dinyatakan dalam tabel 27 sebagai berikut. 
Tabel 7. Persentase Pengamatan Aktivitas Siswa Pertemuan Pertama dan Kedua

\begin{tabular}{|c|c|c|c|c|}
\hline No & Aktivitas & Persentase Pertemuan 1 & Persentase Pertemuan 2 & Rata-rata \\
\hline 1 & Listening activities & $78.47 \%$ & $86.96 \%$ & \multirow{5}{*}{$63.89 \%$} \\
\hline 2 & Oral activities & $47.10 \%$ & $53.62 \%$ & \\
\hline 3 & Motor activities & $81.64 \%$ & $89.86 \%$ & \\
\hline 4 & Mental activities & $40.58 \%$ & $50.72 \%$ & \\
\hline 5 & Drawing activities & $44.93 \%$ & $55.07 \%$ & \\
\hline \multirow[t]{3}{*}{6} & Emotional activities & $61.59 \%$ & $76.09 \%$ & \\
\hline & Rata-rata & $59.05 \%$ & $68.72 \%$ & \\
\hline & Kriteria & & Aktif & \\
\hline
\end{tabular}

Dari data persentase aktivitas siswa diperoleh rata-rata dari enam kategori pengamatan, dua kali pertemuan dan tiga orang observer yaitu sebesar $63,89 \%$. Hal ini menunjukkan bahwa aktivitas siswa selama pembelajaran berlangsung berada pada kategori aktif. Dengan demikian dapat disimpulkan bahwa siswa menjadi aktif ketika diterapkan model pembelajaran Talking Stick pada pokok bahasan kubus dan balok di kelas VIII Sekolah Menengah Pertama Torsina 1 Singkawang.

Motivasi belajar siswa diperoleh melalui penyebaran angket setelah kegiatan pembelajaran menggunakan model pembelajaran Talking Stick. Angket diberikan kepada siswa bertujuan untuk mengetahui tanggapan siswa terhadap sejumlah pernyataan pada angket motivasi belajar siswa. Berdasarkan angket yang diperoleh motivasi belajar siswa di kelas eksperimen secara ringkas dapat dilihat pada Tabel 8 sebagai berikut.

Tabel 8. Hasil Keseluruhan Motivasi Belajar Siswa

\begin{tabular}{ccccc}
\hline $\begin{array}{c}\text { Indikator Motivasi } \\
\text { Belajar }\end{array}$ & $\begin{array}{c}\text { Jumlah } \\
\text { Skor Per } \\
\text { Indikator }\end{array}$ & $\begin{array}{c}\text { Skor Rata-rata } \\
\text { Seluruh Siswa } \\
\text { Disetiap Indikator } \\
(\mathbf{M})\end{array}$ & $\begin{array}{c}\text { Skor Total Rata- } \\
\text { rata Seluruh } \\
\text { Siswa Disetiap } \\
\text { Indikator (Mt) }\end{array}$ & Kriteria \\
\hline $\begin{array}{c}\text { Hasrat dan keinginan } \\
\text { berhasil }\end{array}$ & 144 & 0.78 & 78 & Tinggi \\
\hline $\begin{array}{c}\text { Dorongan dan } \\
\text { kebutuhan dalam belajar }\end{array}$ & 212 & 0.77 & 77 & Tinggi \\
\hline $\begin{array}{c}\text { Harapan dan cita-cita } \\
\text { masa depan }\end{array}$ & 150 & 0.82 & 82 & Tinggi \\
\hline $\begin{array}{c}\text { Kegiatan menarik } \\
\text { dalam belajar }\end{array}$ & 243 & 0.88 & 88 & Sangat Tinggi \\
\hline Jumlah & 749 & 3.25 & 325 & Tinggi \\
\hline Rata-rata Skor Total & & & 81.25 & Tinggi \\
\hline
\end{tabular}

Berdasarkan hasil perhitungan angket motivasi belajar dengan indikator kegiatan menarik dalam belajar yang diperoleh motivasi belajar siswa tinggi. Untuk indikator hasrat dan keinginan berhasil, harapan dan cita-cita masa depan, dorongan dan kebutuhan dalam belajar dari ketiga indikator tersebut diperoleh motivasi belajar siswa tinggi. Selain itu, jika dilihat dari motivasi belajar siswa terhadap setiap butir pernyataan, diperoleh rata-rata jumlah skor total seluruh indikator motivasi belajar diperoleh rata-rata skor total sebesar 81,25 dengan kriteria motivasi belajar siswa tinggi. Sehingga, dengan demikian dapat disimpulkan bahwa pada pokok bahasan kubus dan balok dengan menggunakan model pembelajaran Talking Stick model pembelajaran Talking Stick adalah tinggi. Hasil ini sejalan dengan penelitian yang dilakukan oleh Lilik Hidayati (2013) mengemukakan bahwa 
penerapan kolaborasi metode Talking Stick dan Student Facilitator and Explaining dapat meningkatkan motivasi dan hasil belajar siswa kelas X TKJ SMKN 2 Lingsar Tahun Pelajaran 2013/2014.

\section{KESIMPULAN DAN SARAN}

Berdasarkan analisis data hasil penelitian yang dilakukan dan pembahasan secara umum dapat disimpulkan bahwa model pembelajaran Talking Stick efektif diterapkan untuk meningkatkan kemampuan pemahaman konsep matematis siswa pada materi himpunan di kelas SMP Negeri 9 Singkawang. Dikatakan efektif, karena secara khusus telah memenuhi beberapa hal sebagai berikut. (1) Berdasarkan analisis data yang diperoleh bahwa $t_{\text {hitung }}=6,112>t_{\text {tabel }}=2,00$, sehingga terdapat perbedaan peningkatan kemampuan komunikasi matematis siswa di kelas kontrol dan di kelas eksperimen pada materi kubus dan balok di kelas VIII SMP Torsina 1 Singkawang. (2) Ketuntasan belajar siswa setelah digunakan model pembelajaran Talking Stick di kelas eksperimen lebih tinggi dari pada di kelas kontrol yang menggunakan model pembelajaran langsung yaitu 70,8 > 59,6. Untuk KKM 68, hal ini menunjukkan bahwa kelas kelas eksperimen lebih tinggi dari pada KKM yaitu 70,8 > 68. Sehingga kelas eksperimen ketuntasan belajar siswa dikategorikan tuntas. (3) Aktivitas siswa terhadap model pembelajaran Talking Stick pada materi kubus dan balok di kelas VIII SMP Torsina 1 Singkawang diperoleh rata-rata aktivitas siswa sebesar 80,26\%, dengan kategori aktif. Motivasi belajar siswa pada materi himpunan dengan model pembelajaran Talking Stick diperoleh rata-rata jumlah skor total seluruh indikator motivasi belajar sebesar 81,25 dengan kategori tinggi.

Berdasarkan hasil penelitian, saran dalam penelitian ini adalah sebagai berikut.

1. Bagi siswa untuk menambah semangat untuk lebih aktif dalam belajar, untuk lebih meningkatkan kemampuan komunikasi matematis siswa, berpikir positif bahwa matematika bukanlah pelajaran yang yang sulit dan berusaha untuk menyenangi matematika.

2. Bagi guru mata pelajaran dapat menjadikan model pembelajaran Talking Stick sebagai alternatif model belajar yang relevan selain pembelajaran langsung sehingga dapat membantu siswa dalam menyelesaikan soal-soal yang berkaitan dengan kemampuan komunikasi matematis siswa dan materi kubus dan balok.

3. Bagi peneliti, penelitian ini sangat bermanfaat dalam menambah wawasan dan ilmu pengetahuan untuk bekal masa depan sehingga dapat menjadi lebih baik lagi, karena melalui penelitian ini peneliti mendapatkan pengalaman tentang model pembelajaran yang baik .

4. Kepada peneliti yang ingin melakukan penelitian seperti ini disarankan untuk dapat melakukan penelitian pada materi dan kelas yang berbeda agar diperoleh hasil penelitian yang menyeluruh sehingga dapat dijadikan sebagai bahan referensi.

Demikian kesimpulan dan saran dari peneliti. Semoga dikemudian hari skripsi ini dapat bermanfaat bagi pembaca, terutama bagi saya calon pendidik yang akan menjalankan profesi sebagai pendidik dalam rangka meningkatkan mutu pendidikan.

\section{DAFTAR PUSTAKA}

Buyung, B., \& Nirawati, R. (2018). Pengaruh Karakter Kerja Keras Terhadap Kemampuan Literasi Matematis Siswa Melalui Model Discovery Learning. JPMI (Jurnal Pendidikan Matematika Indonesia), 3(1), 21-25.

Fujioka, Kimberly. 2012. The Talking Stick: An American Indian Tradition in the ESL Classroom. The Internet TESL Journal. 4(9) ,14 Maret 2012. 
Hidayati, Lilik. 2014.Penerapan kolaborasi metode pembelajaran Talking Stick dan student facilitator and explaining untuk meningkatkan motivasi dan hasil belajar matematika siswa kelas x di smk 2 lingsar. Jurnal Pendidikan Matematika.1(1), Maret-Sepember 2014.

Jihad, Asep dan Haris, Abdul. 2008. Evaluasi Pembelajaran. Yogyakarta: Multi Pressindo.

Majid, Abdul. 2009. Perencanaan Pembelajaran. Bandung: PT Remaja Rosdakarya.

NCTM. 2000. Principles and Standardr for School Mathematics. Reston: United States of America.

Priyo, Bambang. 2012.Peningkatan Kemampuan Komunikasi Matematis dan Hasil Belajar Matematika Melalui Metode Talking Stick. jurnalPendidikan Matematika.14(1), ISSN: 2337-4411

Rusman. 2012. Model-model Pembelajaran: Mengembangkan Profesionalisme Guru. Jakarta: PT Raja Grafindo Persada.

Sardiman. 2014. Interaksi dan Motivasi Belajar Mengajar. Jakarta: PT Raja Grafindo Persada.

Sumiati dan Asra. 2011. Metode Pembelajaran. Bandung: CV Wacana Prima.

Wahyuni, Rika dkk. 2018. Efektivitas Model Pembelajaran Creative Problem Solving (CPS) Dalam Meningkatkan Kemampuan Berfikir Kritis Matematis Siswa Pada Materi Persamaan Garis Lurus. Jurnal Pendidikan Matematika Indonesia. 3(1) bulan Maret 2018. Page 26-31, pISSN: 2477-5967 e-ISSN: 2477-8443 